\title{
The analysis of atmospheric and marine dynamics in Java Island during Cempaka Tropical Cyclone
}

\author{
Reynold Mahubessy ${ }^{\text {a,* }}$, Andreas Kurniawan Silitonga, Giofani Pratiwi Lumbantobing and \\ Hasti Amrih Rejeki \\ ${ }^{1}$ Meteorology Department, School of Meteorology, Climatology and Geophysics, Tangerang \\ Selatan, Indonesia \\ a.reynoldmahubessy@gmail.com \\ *corresponding author
}

Keywords: $\quad$ Tropical Cyclone, rainfall, ocean wave height.

Abstract: Indonesia is a tropical area with relatively high irradiation causes the rising of sea surface temperatures. The result is center of low pressure area which can trigger the formation of tropical cyclone which started by the formation of tropical disturbances such as tropical depressions, tropical storms and finally become a tropical cyclone. The objective of this research is to analyse of atmospheric and marine dynamics in Java Island during Cempaka Tropical Cyclone using parameters such as rainfall, wind, and sea wave height. Those parameters can represent the dynamic analysis of the atmosphere and waters in the Java Island during Cempaka Tropical Cyclone. Descriptive analysis is used as the method for this research. The results of data analysis showed that Cempaka Tropical Cyclone gives an impact as bad weather such as rain with moderate to heavy intensity in the South, West Java, Central Java, Yogyakarta, East Java, and Bali. The amount of rainfall on Monday, November 27, 2017, in one day reached 364.1 millimeters in Sleman, Yogyakarta and it categorized as very heavy rainfall. The southern area of Cianjur, Garut, Tasikmalaya and Pangandaran on 27-28 November 2017 was also heavy rain. In addition, the potential for high speed winds can reach up to 30 knots occured in the Mentawai Islands, Bengkulu, South Sumatra, Bangka Belitung, Lampung, Banten, Jakarta. The other impacts of high waves 1.25 - 2.5 meters occured in the South Sea of Bali to Sumba Island, Bali Strait, the Lombok Strait, and the South of Alas Strait and high waves $2.5-4.0$ meters in the South Sea of Central Java to East Java, and Bali.

\section{Introduction}

Tropical cyclone is a form of extreme weather disruptions that preceded the emergence of the low pressure center over the ocean that triggered the process of convection and cloud formation intensively. Tropical cyclone is one of the most potentially destructive extreme events that result in severe loss to the country in terms of life and property. The impact of these events in the changing climate scenario is of extreme importance and is a widely debated topic [1]. A tropical cyclone is an atmospheric cyclonic system that originates the tropical oceans, and is driven principally by heat transfer from the ocean [2]. 
Tropical cyclone formation is generally effective in areas above latitude $10^{\circ}$ North latitude or south latitude [3]. Approximately $65 \%$ of tropical cyclone forming in the area between $10^{\circ}$ and $20^{\circ}$ from the equator, and very few $( \pm 13 \%)$ that appeared on the above latitude $22^{\circ}$, as well as the tropical cyclone will not appear in the region of $4^{\circ}$ from the Equator [4]. Indonesia is located in the region of the Equator (Equatorial), at $95^{\circ} \mathrm{E}$ and $140^{\circ} \mathrm{E}$ to $6^{\circ} \mathrm{N}$ to $11^{\circ} \mathrm{S}$. Location of Indonesia led to only a fraction of the territory that Indonesia may be able to experience the tropical cyclone events. This is because the region around the Equator has the style of a small yet coriolis effect coriolis is the driving force of the early rounds of the cyclone [7]. Generally, tropical cyclone (65\%) occurred in the area of latitude $10^{\circ}$ to $20^{\circ}$, and very few $( \pm 13 \%)$ that appeared on the above latitude $22^{\circ}$, as well as the tropical cyclone will not appear in the region of $4{ }^{\circ}$ from the Equator [4]. Indonesia region relatively free of tropical cyclone but the effects can still be felt. That is because the influence of the vortex of winds that bring clouds from tropical cyclones may reach the territory of Indonesia. However, the impact of tropical cyclones on Indonesia is quite visible, especially in areas close to the tropical cyclone growth region [5].

The incidence of tropical cyclones in the region of Australia has always appeared in the southern part of Indonesia every year between January and March, caused by high sea-surface temperatures in the South of Indonesia and the movement of the Inter Tropical Convergence Zone (ITCZ) towards North [6]. Growth and movement of the tropical cyclone can be observed by monitoring the activity of the convective as any tropical cyclone wind eddies occur is always accompanied with the convective clouds that come into spin.

On November 27, 2017 some areas in Indonesia, especially Java island hit by heavy rain with a duration of sufficient length. It is triggered by changes in weather patterns as the impact from tropical cyclones are growing very close to the South coast of Java island by the name of Cempaka. Cempaka tropical cyclone formed from the low pressure Centre and found since Monday night, starting at 19.00 GMT. Cempaka tropical cyclone formed in waters south of Java on a $100 \mathrm{~km}$ south southeast of Cilacap.

\section{Data and Method}

\subsection{Study Area}

This research was conducted in the area of Central Java ( $7^{\circ} 30^{\prime} 0$ "S/110 $0^{\circ}$ ' 0 " E) and Yogyakarta $\left(8^{\circ} 30^{\prime}-7^{\circ} 20^{\prime} \mathrm{S} 109^{\circ} 40^{\prime}-111^{\circ} 0{ }^{\prime} \mathrm{E}\right)$.

This region is a region of Cempaka tropical cyclone impact with the intensity of a great catastrophe. These disasters include floods, high waves, and strong winds [1].

\subsection{Data}

The data used in this research is the average data of daily rainfall, surface wind $10 \mathrm{~m}$, and wave height data on November, 24-30 2017. Daily rainfall data and wave height daily obtained from the website BMKG (Meteorology Climatology and Geophysics Agency), while for $10 \mathrm{~m}$ surface wind data obtained from ERDDAP which provides oceanographic data (satellite and buoy data) available on NOAA (National Oceanic and Atmospheric Administration) website used to see the direction and speed of movement of Cempaka tropical cyclone.

\subsection{Method}

The methods used in this research is a descriptive analysis to look at the picture and Cempaka tropical cyclone activity. 


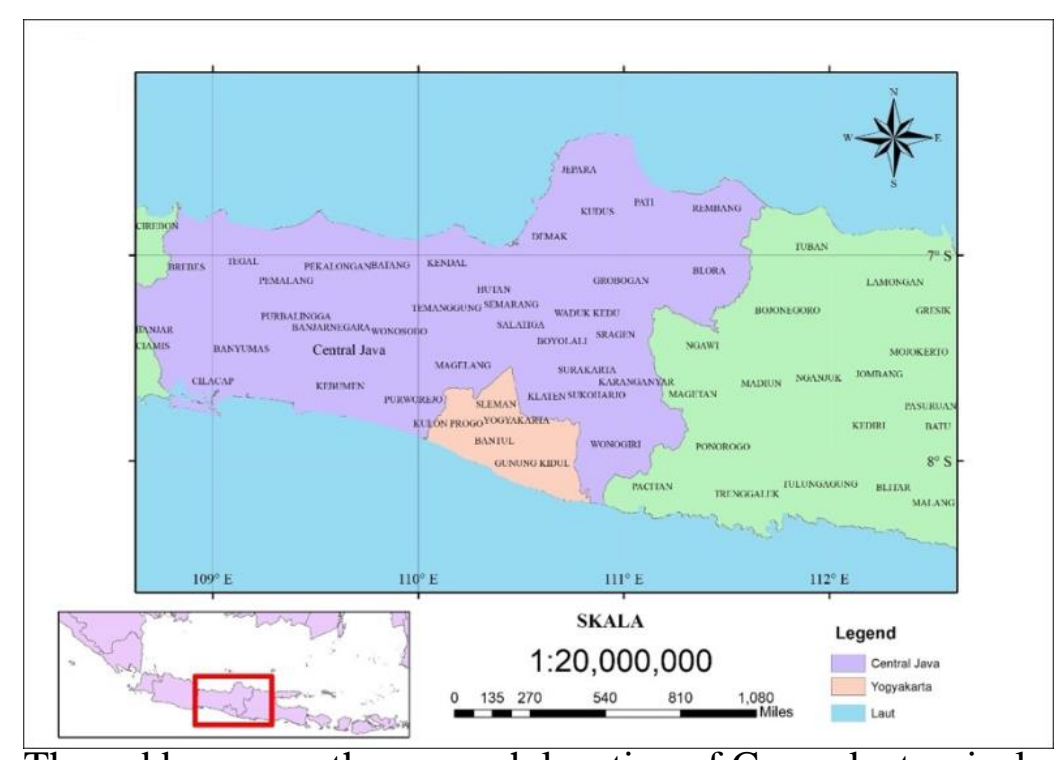

Figure 1. The red boxes are the research location of Cempaka tropical cyclone

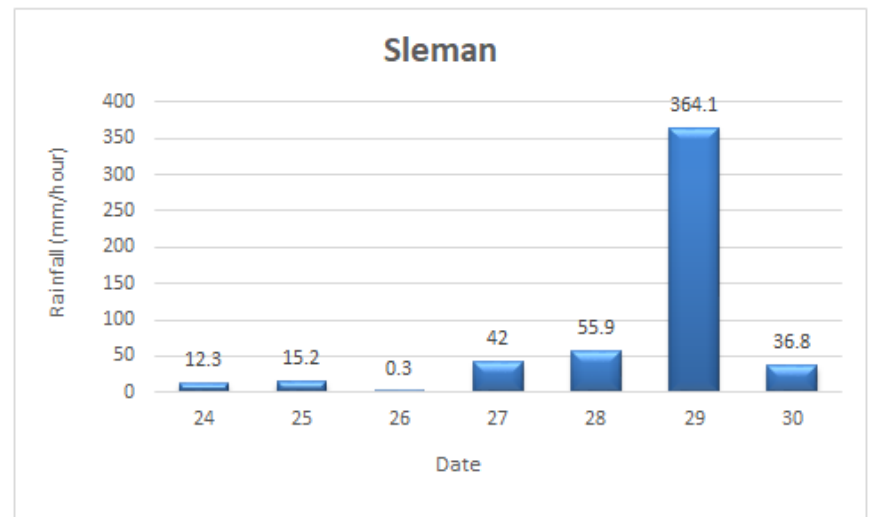

Figure 2. Graph of Sleman rainfall

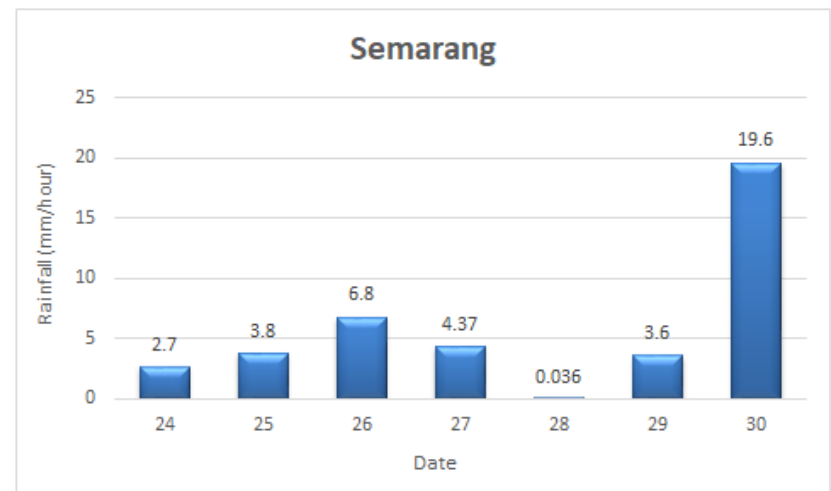

Figure 3. Graph of Semarang rainfall

\section{Result and Discussion}

Based on the graph of the average daily rainfall on 24-30 November 2017 for sleman, Yogyakarta (Figure 2) and Semarang, Central Java (Figure 3) can be seen the highest rainfall intensity each of $364.1 \mathrm{~mm}$ and $19.6 \mathrm{~mm}$. precipitation Intensity the rain increased significantly on the $29^{\text {th }}$ in sleman, Yogyakarta and Semarang in the area on 30. The increased intensity of rainfall causing floods significantly in the area of sleman, Yogyakarta and Semarang. 
Based on figure 4 , wind direction and speed significantly on the $24^{\text {th }}$ seen the position of Cempaka tropical cyclone formed in the southeastern waters of Java Island, seen from its trajectory, the movement of Cempaka cyclone direction on the $25^{\text {th }}$ moving southward waters of Java Island and Cempaka cyclone continues to grow close to the mainland Java Island with high wind speed reached 30 knots. On the $27^{\text {th }}$ is the peak of Cempaka's tropical cyclone life that continues to move towards the East of Java Island with constant speed causing some areas such as Central Java, Yogya and East Java to be exposed to extreme weather such as experiencing high intensity rain that causes flooding in the area. Cempaka tropical cyclone enter the extinct stage after moving into the land area of East Java Island. This causes on November,28-29 tropical cyclone Cempaka missing in the area.
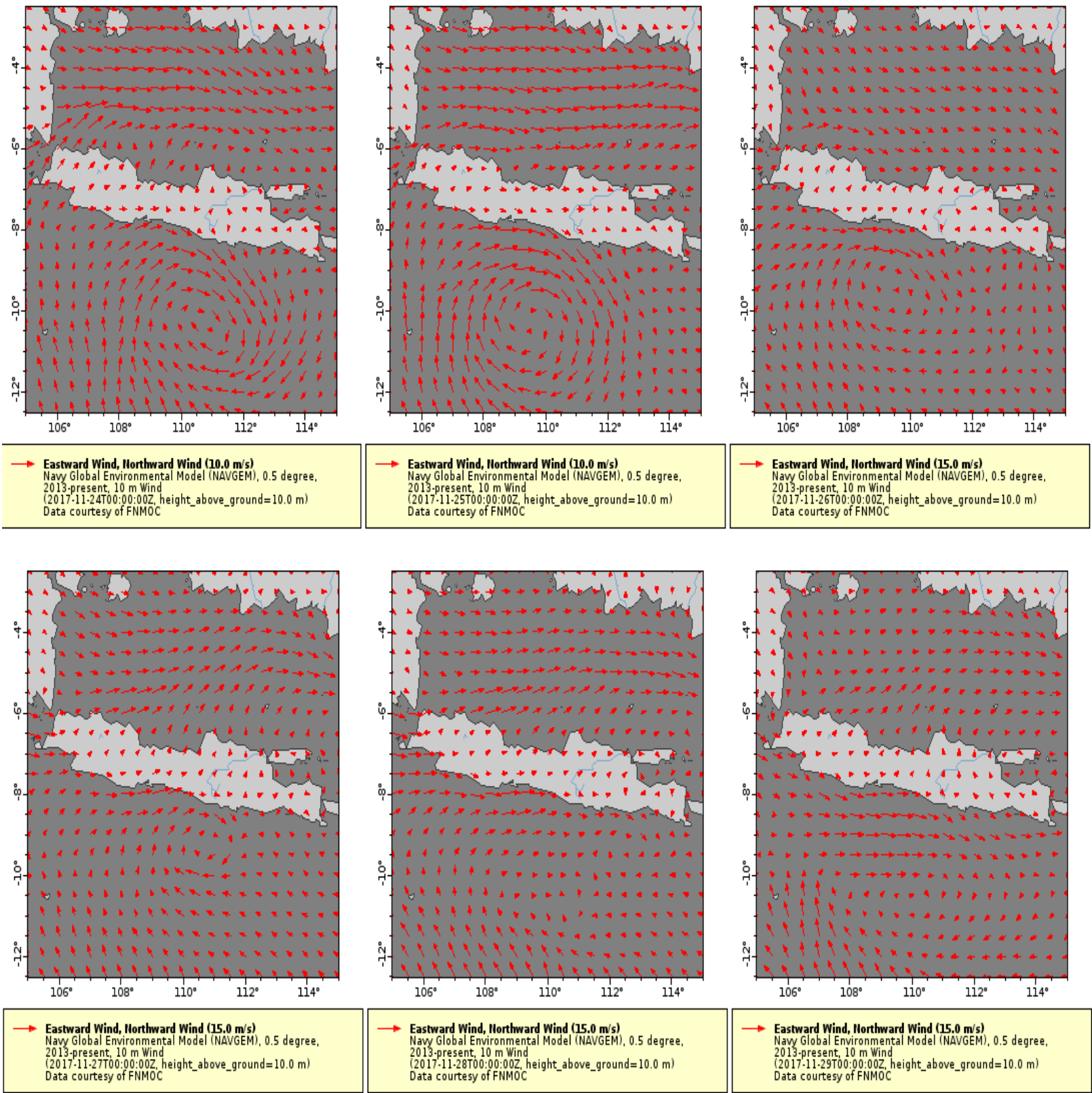

Figure 4. Direction and wind speed on November 24-29,2017 00.00 UTC (Source : ERDDAP NOAA) 


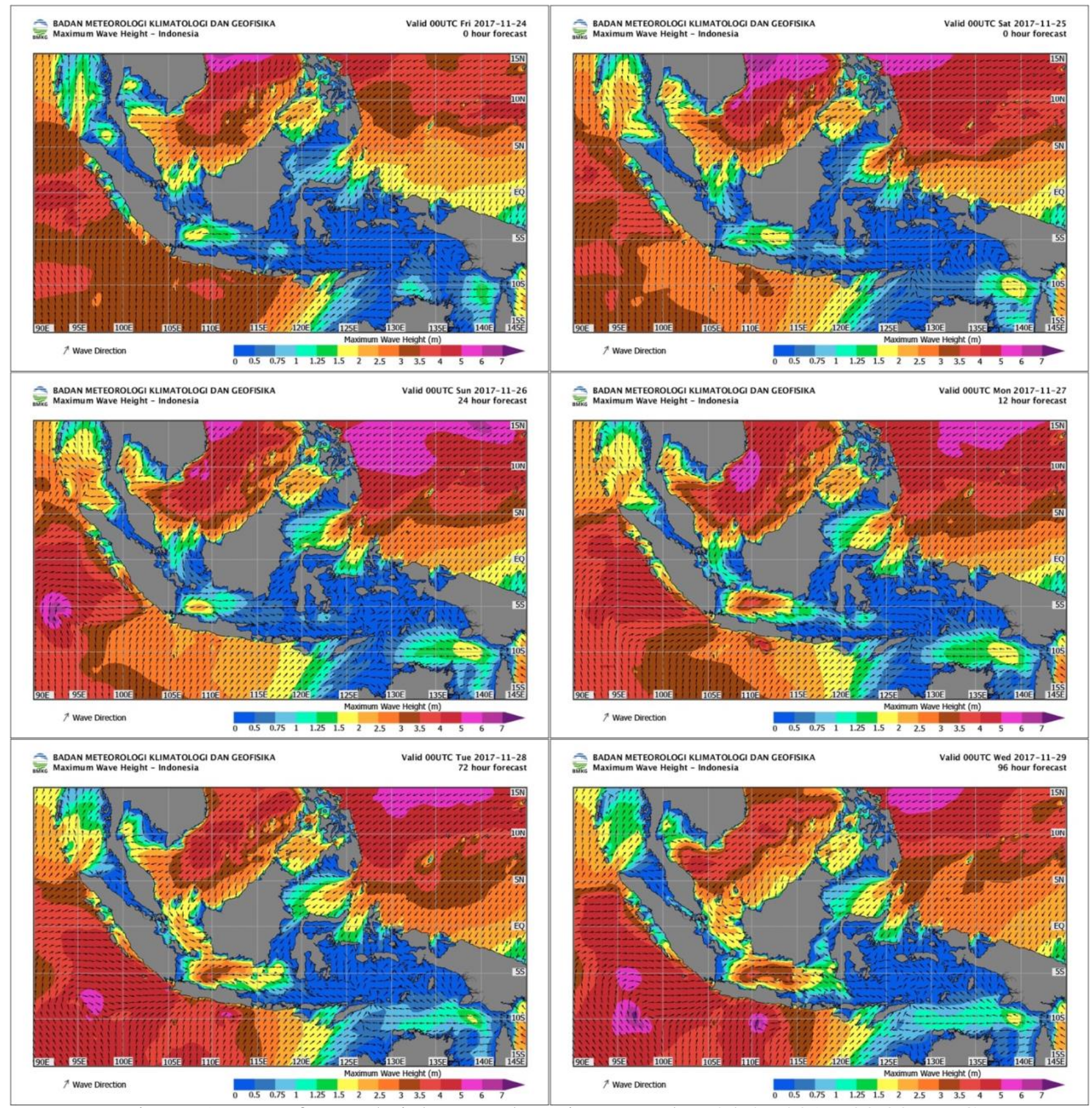

Figure 5. Map of wave height on Indonesia November 24-29,2017 00.00 UTC

(Source: BMKG)

Based on figure 5, it can be seen the impact of Cempaka tropical cyclone which has the potential to generate high waves. Potential wave height of 2.5 meters to 6 meters in South Waters of East Java, East Java Sea, South Sunda Strait, South Waters Banten to West Java, Indian Ocean to South Central Java. This can interfere with international shipping and distribution globally.

\section{Conclusions}

Based on the results of research conducted, it can be concluded that Cempaka tropical cyclone enormous impact in parts of Indonesia especially in Central Java and Yogyakarta. Many consequences posed by this phenomenon as it occurs the heavy rain, strong winds, that cause the 
occurrence of extreme weather that could potentially occur high waves even if there is a high increase in the sea level could cause a wave of storms (storm surge) that can interfere with international shipping.

\section{Acknowledgements}

The authors would like to thank Meteorology Climatology and Geophysics Agency (BMKG) and NOAA for providing data in conducting this research as well as all those who have helped so that this paper can be made.

\section{References}

[1] IPCC 2013: Climate Change 2013: The Physical Science Basis. Contribution of Working Group I to the Fifth Assessment Report of the Intergovernmental Panel on Climate Change [Stocker, T.F., D. Qin, G.-K. Plattner, M. Tignor, S.K. Allen, J. Boschung, A. Nauels, Y. Xia, V. Bex and P.M. Midgley (eds.)].

[2] Emanuel, K. (2003). Tropical cyclones. Annual Review of Earth and Planetary Sciences, 31(1), 75-104.

[3] Zubaidah and Haryani.Tropical Cyclone Dynamics in Southeast Asia Uses Remote Sensing Data, "1-5,2012.

[4] B. Tjasyono, Applied Meteorology. Bandung: Bandung Institute of Technology, 2008.

[5] Kadarsah, 2007. Tropical Cyclone and Tsunami in Indonesia, (https://kadarsah.wordpress.com/2007/08/30/tropicalcyclone-and-tsunami-in-indonesial, accessed 27 January 2017 at 17.00 WIB)

[6] A. Zakir, Tropical Cyclone Review (2006) (http://www.scribd.com/doc/31289081/ cyclone-tropical-study, accessed on January 27th at 5:00 pm)

[7] Mustika, A., 2008. Tropical Cyclone Characteristics Around Ijndonesia, Thesis, Bogor Agricultural University, Bogor.. 